\title{
Moyamoya Disease Associated with Recurrent Right Thalamic Haemorrhage and Hydrocephalus: A Case Report
}

\author{
Nïks Să̆ Talamik Kanama ve Hidrosefali ile İlişkili Moyamoya \\ Hastalığı: Bir Olgu Sunumu
}

\author{
Rohan SINHA ${ }^{1}$, Amit Kumar JAIN ${ }^{2}$, Nitin JAGDHANE ${ }^{1}$, Parvati NANDY², Satish Kumar KHANNA ${ }^{3}$ \\ ${ }^{1}$ Sikkim Manipal Institute of Medical Sciences, Central Referral Hospital, Department of Neurosurgery, Gangtok, Sikkim, India \\ ${ }^{2}$ Sikkim Manipal Institute of Medical Sciences, Central Referral Hospital, Department of Medicine, Gangtok, Sikkim, India \\ ${ }^{3}$ Sikkim Manipal Institute of Medical Sciences, Central Referral Hospital, Department of Radiodiagnosis, Gangtok, Sikkim, India
}

Corresponding Author: Rohan SINHA / E-mail: drrohansinha@gmail.com

\begin{abstract}
Moyamoya disease, a rare chronic, progressive cerebrovascular disease leads to occlusion of intracranial internal carotid arteries and its proximal branches. We report a case of a 51-year-old female who presented with recurrent thalamic bleed and intraventricular haemorrhage nine years apart in the same territory. The first bleed was managed conservatively and second bleed led to development of hydrocephalus. The acute phase of the hydrocephalus was managed by external ventricular drainage and the final CSF diversion was managed by ventriculoperitoneal shunt. The definitive treatment could not be done to denial of consent from the patient. We present the case to highlight the role CSF diversion as a means of palliative treatment for the Moyamoya disease.
\end{abstract}

KEYWORDS: Moyamoya disease, Adult, Haemorrhage, Hydrocephalus, Ventriculoperitoneal shunt

öz

Nadir, kronik ve progresif bir serebrovasküler hastalık olan Moyamoya hastalığı intrakraniyal internal karotid arterler ve proksimal dallarında tıkanmaya neden olur. Aynı bölgede dokuz yıl arayla nüks talamik ve intraventriküler kanamayla gelen 51 yaşında bir kadın hasta sunuyoruz. ilk kanama konservatif olarak izlenirken, ikinci kanama hidrosefali gelişmesine neden oldu. Hidrosefalinin akut fazı eksternal ventriküler direnajla tedavi edildi ve takiben ventrikülo-peritoneal şant uygulandı. Hasta olur vermediği için kesin tedavi yapılamadı. Olguyu moyamoya hastalığının palyatif tedavisi için beyin omurilik sıvısı (BOS) dolanımının rolünü vurgulamak üzere sunuyoruz.

ANAHTAR SÖZCÜKLER: Moyamoya hastalığı, Yetişkin, Kanama, Hidrosefali, Ventriküloperitoneal şant

\section{INTRODUCTION}

Moyamoya disease (MMD) is a rare bilateral steno occlusion of the internal carotid artery (ICA) (4), and it is an essential criterion on conventional angiography for the diagnosis (8). The disease mostly occurs in Japanese, Asians and nonCaucasians (3). It also affects patients in the United States, Western Europe and Australia (10). The condition is observed mainly in infants, children and adolescents (10); seemingly more in females (9). Adults experience more commonly haemorrhages; where as children more commonly have cerebral ischemic events (12). Rarely the haemorrhages recur and may complicate the outcome. Curative treatment does not exist and treatment in the acute phase is symptomatic. Surgical methods are used to restore and maintain adequate cerebral perfusion by revascularization procedures. Haemorrhagic cases are usually treated conservatively and at times uncommonly ventricular drainage may be required (2).

\section{CASE REPORT}

A 51-year-old female had spontaneous right thalamic bleed and intraventricular haemorrhage (IVH) 9 years back (Figure $1 \mathrm{~A})$. She was diagnosed MMD based on the angiography demonstrating bilateral intracranial ICA stenosis with puff of smoke appearance (Figure 2A). She did not consent for revascularisation procedure. After being asymptomatic for nine years, she presented with generalized headache for 5 days and sleepiness for 2 days without vomiting, blurring of vision, convulsions or trauma. She had Glasgow Coma Scale (GCS) of 13/15 (E3V4M6) \& bilateral $3 \mathrm{~mm}$ pupils reacting to light normally. She had left hemiparesis (4/5) and neck rigidity. Non contrast computed tomography (CT) head was suggestive of right thalamic bleed and IVH at same place (Figure 1B) and CT cerebral angiography demonstrated bilateral stenosed ICA (Figure 2B). She was managed conservatively; but on the fourth day on clinical deterioration to GCS 9/15 (E2V2M5) her repeat Non contrast CT head suggested increase in hydrocephalus. External ventricular 
drainage (EVD) through right frontal horn was performed (Figure 3A). She gradually improved EVD was converted to right ventriculo peritoneal (VP) medium pressure shunt. After 12 hours of transient improvement she deteriorated and Non contrast CT head revealed left frontal and parietal haemorrhage with subarachnoid haemorrhage $(\mathrm{SAH})$ (Figure $3 \mathrm{~B})$. She improved gradually on conservative management \& at three month follow up patient is conscious, alert, has dementia, has no limb deficit but has bladder incontinence.

\section{DISCUSSION}

MMD was first described by Takeuchi (14) and Suzuki (13). The age of presentation in adults is in 40s. The common clinical presentation in the adults is haemorrhage similar to a stroke. One fifth of the patients with MMD in Japan have haemorrhagic presentation. Haemorrhages can be due to breakdown of dilated friable perforating vessels that form the extensive basal collateral network (15). SAH in MMD is due to formation of pseudoaneurysm or microaneurysm (7). About $40 \%$ are IVH and intracerebral haemorrhage (ICH) together, followed by simple IVH, simple ICH and SAH. The ICH is most commonly in the basal ganglia region $(6,11)$. Thalamic bleed is relatively uncommon and found in about $21.4 \%$ patients (6). Multiple bleeding (re-bleeding) has been reported to be about $18 \%$ (5) and 34\% (6) characterized mainly by the change in site and type of bleeding pattern with a rate of about $70 \%$ (6). The second bleed in the same site and type is relatively uncommon, as was seen in our case. Cerebral angiography demonstrates stenosis at the terminal portion of the ICA and / or the proximal portion of the anterior or middle cerebral arteries associated with abnormal vascular networks in the vicinity (12). The findings are usually bilateral from grades I-VI (13) (based on ICA stenosis and external carotid artery collaterals). Different stages can be found in the same patient in both hemispheres. The present patient's angiography clearly demonstrates extensive collaterals in left ICA compared to reduced number of collaterals in right ICA.

Optimal management of MMD is still debatable and no known treatment is curative. The treatment in the acute phase is symptomatic with the goal of maintaining cerebrovascular perfusion and function (1). Surgical treatment modalities have

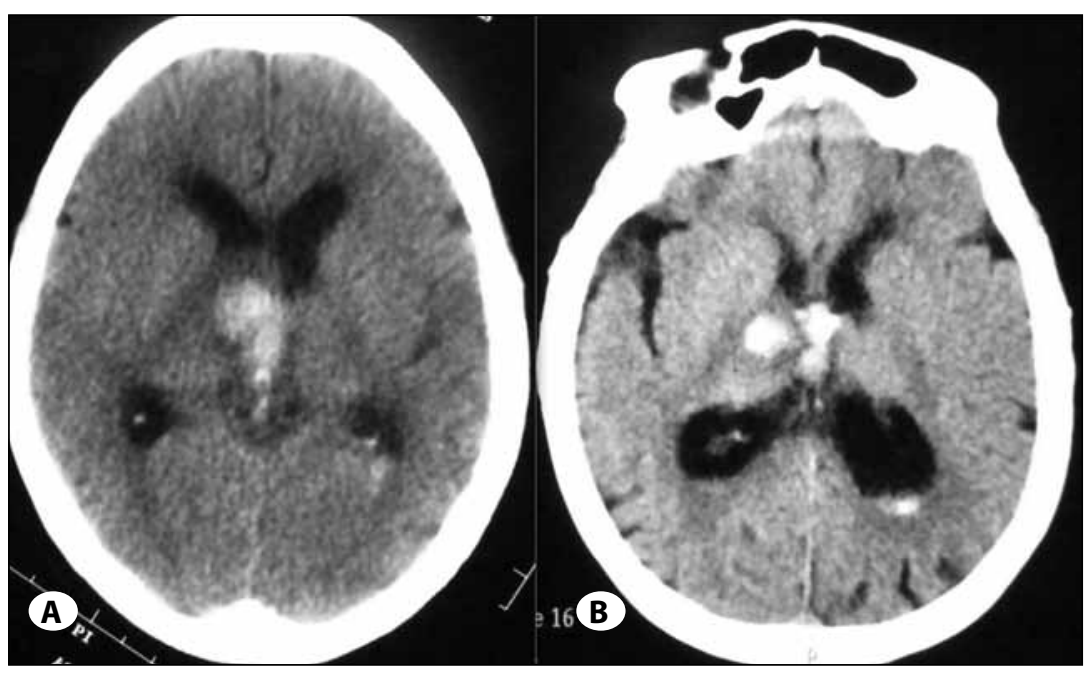

Figure 1: Non contrast CT scan of head showing right thalamic and IVH nine years back $(\mathbf{A})$ and recurrent bleed in the same site with the same pattern (B).

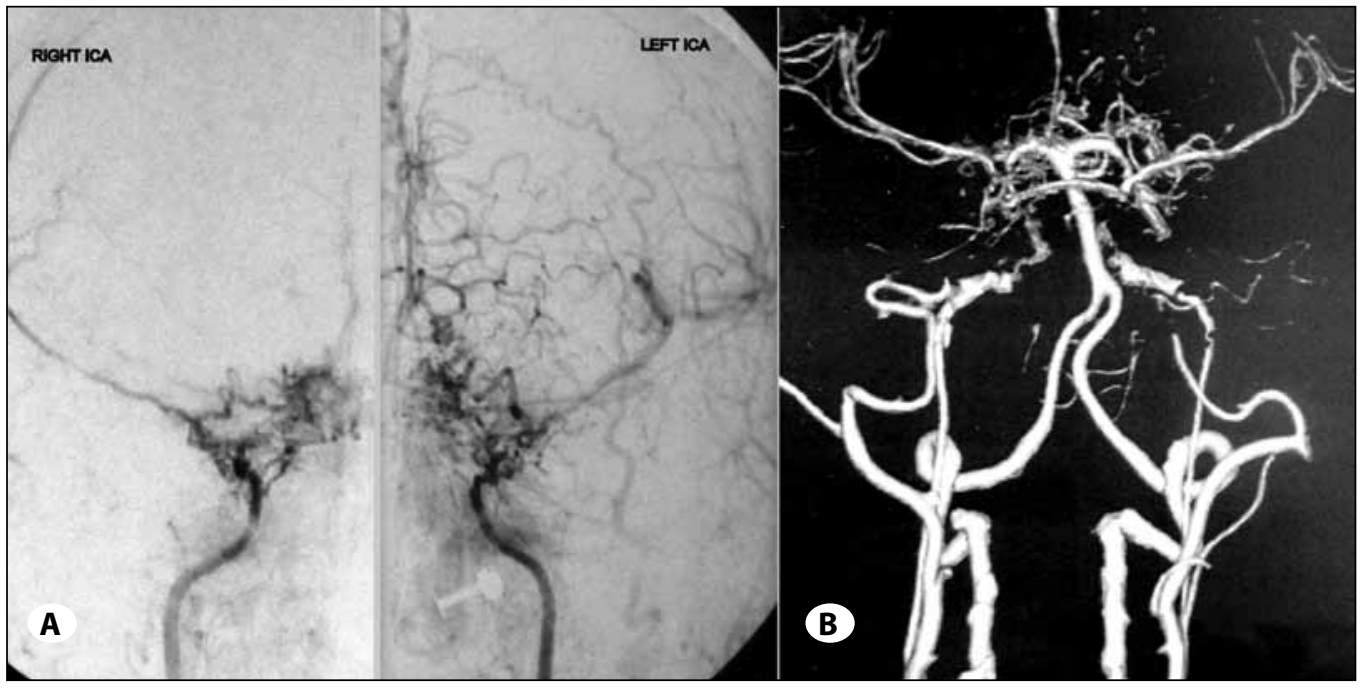

Figure 2: Cerebral angiography showing stenosed intracranial ICA with puff of smoke appearance in different grades $(\mathbf{A})$ and similar findings on CT cerebral angiography (B). 


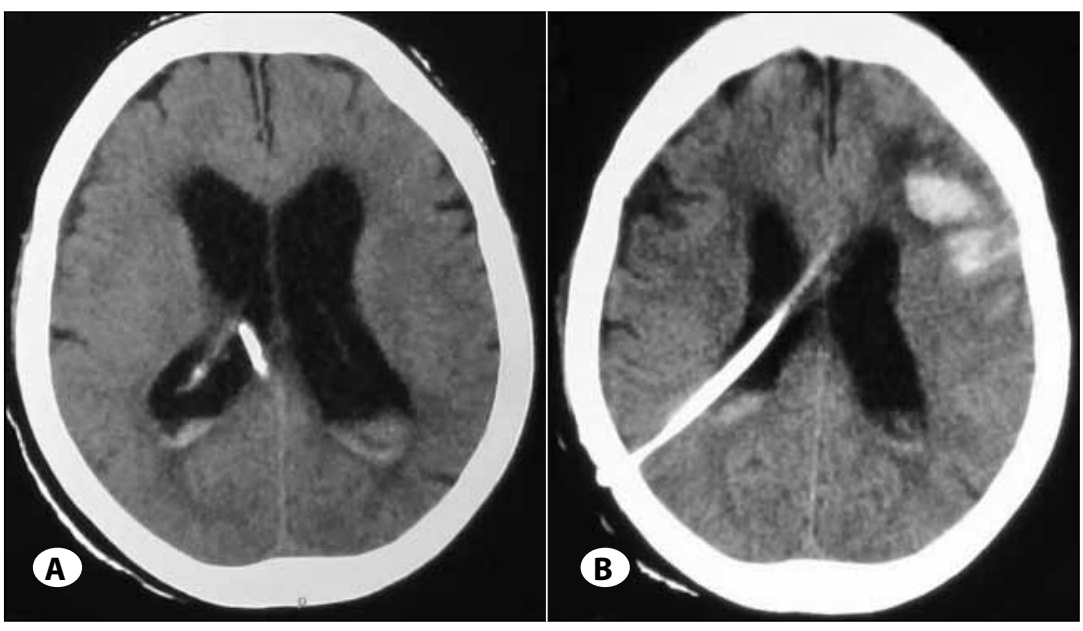

Figure 3: Non contrast CT scan of head showing EVD in situ (A) followed by right VP shunt along with left ICH (B). been used to manage the haemorrhagic and ischemic consequences of MMD to restore and maintain adequate cerebral perfusion. Two main surgical revascularization procedures have been described: direct and indirect. Direct revascularization techniques, commonly used in adults, include the superficial temporal artery to middle cerebral artery bypass or the middle meningeal artery to middle cerebral artery bypass (3). The objective of indirect surgical procedures, in children, is to increase the volume of circulation in the collateral vasculature. Techniques include encephaloduroarteriomyosynangiosis, encephaloduroarteriosynangiosis, encephalomyoarteriosynangiosis, and encephalomyosynangiosis (1). Ventricular drainage and hematoma evacuation are used at times for haemorrhagic cases. The ventricular drainage clears the IVH but can result in the formation of communicating hydrocephalus in these patients. The incidence of development of hydrocephalus in such patients of MMD has not been clearly defined. The hydrocephalus needs a cerebrospinal fluid diversion procedure for the prevention of further damage to the brain. The procedure commonly performed is VP shunt. The ventricular drainage and/or VP shunt was performed in 19\% by Kobayashi et al. (6) and in $15.8 \%$ by Ikezaki (5). The role and indication of VP shunt or ventricular drainage has not yet clearly been defined. The present patient needed ventricular drainage and subsequently VP shunting. The role of VP shunting perhaps remains in those patients who have IVH leading to hydrocephalus. The long-term outcome of these patients needs to be studied.

\section{REFERENCES}

1. Chiu D, Shedden P, Bratina P, Grotta JC: Clinical features of moyamoya disease in the United States. Stroke 29(7):13471351,1998

2. Fukui M: Guidelines for the diagnosis and treatment of spontaneous occlusion of the circle of Willis (Moyamoya' disease). Clinical Neurology and Neurosurgery 99: S238-S240, 1997

3. Goto Y, Yonekawa Y: Worldwide distribution of moyamoya disease. Neurologia Medico-Chirurgica 32(12): 883-886, 1992
4. Houkin K, Abe H, Yoshimoto T, Takahashi A: Is "unilateral" moyamoya disease different from moyamoya disease?. Journal of Neurosurgery 85(5): 772-776, 1996

5. Ikezaki K, Fukui M, Inamura T, Kinukawa N, Wakai K, Ono Y: The current status of the treatment for hemorrhagic type moyamoya disease based on a 1995 nationwide survey in Japan. Clinical Neurology and Neurosurgery 99: S183-S186, 1997

6. Kobayashi E, Saeki N, Oishi H, Hirai S, Yamaura A: Long-term natural history of hemorrhagic type moyamoya disease in 42 patients. Journal of Neurosurgery 93(6): 976-980, 2000

7. Massoud TF, Guglielmi G, Vinuela F, Duckwiler GR: Saccular aneurysms in moyamoya disease: Endovascular treatment using electrically detachable coils. Surgical Neurology 41(6): 462-467, 1994

8. Nishimoto A, Ueda K, Homna Y: Follow-up study on outcome of the occlusion of the circle of Willis. In: Goth S (ed), Proceedings of the Research Committee on Spontaneous Occlusion of the Circle of Willis. Tokyo: Ministry of Health and Welfare, 1983: 66-74

9. Piepgras DG: Moyamoya disease. In: Williams R, Rengalchari S (eds), Neurosurgery. New York: McGraw-Hill Book Company, 1987: 1254-1258

10. Ropper AH, Samuels MA: Cerebrovascular disease. In: Adams and Victor's, Principles of Neurology. New York: McGraw-Hill Inc., 2009: 797-797

11. Scott RM, Smith ER: Moyamoya disease and moyamoya syndrome. New England Journal of Medicine 360(12):12261237, 2009

12. Sucholeiki R, Chawla J: Moyamoya Disease (eMedicine website). January 25, 2012. Available at: http://emedicine. medscape.com/article/1180952-clinical. Accessed March 27, 2014

13. Suzuki J, Takaku A: Cerebrovascular "moyamoya" disease: Disease showing abnormal net-like vessels in base of brain. Archives of Neurology 20(3): 288-299, 1969

14. Takeuchi K, Shimizu K: Hypoplasia of the bilateral internal carotid arteries. Brain Nerve 9: 37-43, 1957

15. Yamashita M, Oka K, Tanaka K: Histopathology of the brain vascular network in moyamoya disease. Stroke 14(1): 50-58, 1983 